\title{
Manejo perioperatorio de feocromocitoma en una paciente embarazada
}

\author{
Sánchez Crocci F. ${ }^{1}$, Vincenti AA. ${ }^{1}$, Lawrynowicz M. ${ }^{1}$, Gelhorn MN. ${ }^{1}$ \\ 1 Hospital Zonal General de Agudos Evita Pueblo, Berazategui, Argentina.
}

Introducción: Los feocromocitomas son tumores neuroendocrinos infrecuentes de la médula adrenal. Producen excesivas cantidades de catecolaminas, generando, especialmente durante la inducción anestésica o la intervención quirúrgica, alteraciones hemodinámicas importantes.

Su asociación con el embarazo es muy poco frecuente $(0,07-0,013 \%)$ y la similitud entre sus manifestaciones y la eclampsia dificultan el diagnóstico.

Caso clínico: A.M 38 años, 82 kg, 1,70 mts, embarazada de 20 semanas, G6 P4 A1, con antecedentes de hipertensión y diabetes pregestacional, consultó por eclampsismo. Luego de la evaluación clínica, se arribó a la sospecha de feocromocitoma (ecografía abdominal que evidenció imagen solida en polo superior del riñón y medición de ácido vanilmandélico en orina de 24 h) y se decidió la extirpación quirúrgica vía laparoscópica, previo tratamiento alfabloqueante con doxazocina durante 10 días. La paciente recibió además tratamiento con labetalol.

Ingresó a quirófano con 22,5 semanas de gestación. Se colocó acceso venoso 16 G, monitores de ECG, PANI, oximetría de pulso, premedicación con midazolam $3 \mathrm{mg}$, analgésica subaracnoidea con morfina $200 \mathrm{mcg}$. Se canalizó arteria radial para medición de TA invasiva. Previa preoxigenacion (EtO2 $>90 \%$ ), se indujo la anestesia con fentanilo $250 \mathrm{mcg}$, propofol $100 \mathrm{mg}$ y vecuronio $8 \mathrm{mg}$. Se realizó IOT, colocación de acceso venoso central, sonda vesical y posicionamiento en decúbito lateral izquierdo. El mantenimiento se realizó con sevofluorano 1,5\% y remifentanilo TCI $8 \mathrm{ng} / \mathrm{ml}$.

Al producirse un descenso progresivo de la TA, se expandió con $200 \mathrm{ml}$ de cristaloides. Ante la falta de respuesta, se inició infusión con noradrenalina, cuya dosis debió aumentarse progresivamente con leve modificación de la TA. Se decidió infundir adrenalina $0,1 \mathrm{mcg} / \mathrm{kg} / \mathrm{min}$ con normalización de dicha variable. Se realizaron controles de medio interno cada 30 minutos durante los 90 minutos de cirugía, sin más alteraciones hemodinámicas. Al finalizar la misma, se trasladó a UTI extubada.

El diagnóstico de feocromocitoma fue confirmado por inmunohistoquimica.

Conclusión: En concordancia con la bibliografía publicada, logrado el diagnostico de feocromocitoma, para conseguir un buen control hemodinámico intraoperatorio debe realizarse un adecuado bloqueo alfa durante 10-14 días.

La cirugía es el tratamiento de elección del feocromocitoma durante el embarazo, y debería practicarse antes de las 24 semanas de gestación, ya que más allá el tamaño uterino dificultaría su exéresis.

Es clave en el manejo anestésico minimizar la ansiedad, garantizar un plano anestésico profundo durante la IOT y cirugía, monitoreo invasivo de TA y utilización de drogas vasoactivas e inotrópicas que rápidamente puedan contrarrestar alteraciones hemodinámicas agudas y pronunciadas.

https://doi.org/10.25237/congresoclasa2019.67 